\title{
PRZYGOTOWANIE DO PLANOWANIA KARIERY ZAWODOWEJ - W OPARCIU O ZALOŻENIA I REALIZACJĘ PROJEKTU LEONARDO DA VINCI NAVIGUIDE ${ }^{1}$
}

Doradztwo zawodowe rozumiane jest obecnie jako proces całożyciowy. Zmiana paradygmatu poradnictwa polega, zdaniem Augustyna Bańki, na wyzwalaniu indywidualnej inicjatywy w rozwoju własnego charakteru oraz stymulowaniu elastycznego i pozytywnego nastawienia na zmianę - w obrębie stylów życia, projektów życiowych czy nadawania wartości i znaczeń ${ }^{2}$. Doradztwo edukacyjno-zawodowe w istocie zmienia się w całożyciowe poradnictwo kariery i staje się „odkrywaniem scenariuszy życia"’3, umożliwiających przekraczanie granic, adaptację do różnych środowisk, asymilowanie wzorców pozwalających na mobilność psychiczną. Proces ten nastawiony jest z jednej strony - na całożyciowy rozwój i uczenie się jednostki, a z drugiej - koncentruje się na pomaganiu ludziom na różnych etapach życia, rozwiązywaniu problemów wykraczających poza aspekty zawodowe - jak twierdzi

1 Projekt zrealizowany przy wsparciu finansowym Komisji Europejskiej (Program LLP - Leonardo da Vinci). Projekt i jego treść odzwierciedlają jedynie stanowisko ich autorów i Komisja Europejska nie ponosi odpowiedzialności za umieszczoną w nich zawartość merytoryczną. Numer projektu: LLP-LDV-TOI-LLPLDV-TOI-11-AT-001011AT-0010, strona projektu: www.naviguide.net (otwarty 31.03.2013).

2 Por. A. Bańka, Psychologiczne doradztwo karier, Wydawnictwo Print-B, PoznańWarszawa 2007, s. 28.

3 Tamże. 
A. Bańka - także związane z rozwojem osobowości ${ }^{4}$. Doradztwo kariery ma więc za zadanie nie tyle pomoc $\mathrm{w}$ wyborze zawodu, ile przygotować jednostki do samodzielnego odkrywania możliwości rozwoju i dokonywania zmian.

Istotną, narastającą obecnie, tendencją jest przesuwanie odpowiedzialności za własną karierę i rozwój zawodowy w kierunku jednostki. A. Bańka określa to jako eksternalizację zatrudnienia, rozwoju i odpowiedzialności ${ }^{5}$. Eksternalizacja oznacza, że jednostki (pracownicy) są obarczane odpowiedzialnością za przyszłą sytuację zawodową. Liczne badania prowadzone w polskich przedsiębiorstwach (między innymi $\mathrm{BKL}^{6}$ ) potwierdzają, że pracodawcy coraz chętniej przesuwają odpowiedzialność za dokształcanie, doskonalenie i rozwój zawodowy na pracowników. Uwidacznia to charakterystyczne dla polskiego rynku pracy tendencje takie, jak: zawieranie tzw. „umów śmieciowych”, wymuszanie od pracowników samo zatrudnienia, outsourcing różnorodnych usług (powodujący redukcję zatrudnienia w przedsiębiorstwie) czy też leasing pracowniczy, który z jednej strony zwiększa mobilność zawodową pracowników, a z drugiej powoduje ,rozmycie” odpowiedzialności za ich rozwój zawodowy. Współczesny polski pracobiorca musi być więc sam odpowiedzialny za przebieg i rozwój swojej kariery zawodowej, mimo że często nie jest do tego odpowiednio przygotowany. Rozwinięta na wysokim poziomie subdyscyplina, jaką jest poradnictwo zawodowe, jest na ogół mało dostępna dla przeciętnych uczestników rynku pracy. Praktyka doradcza kierowana jest bowiem głównie do uczniów (i to od niedawna, jak również w niewystarczającym zakresie) oraz osób zarejestrowanych w urzędach pracy. Istnieje zatem potrzeba wdrażania programów z zakresu poradnictwa zawodowego dostępnych

${ }^{4}$ Por. tamże, s. 28-40.

5 Por. A. Bańka, Kapitat kariery: uwarunkowania, rozwój i adaptacja do zmian organizacyjnych oraz strukturalnych rynku pracy, [w:] Współczesna psychologia pracy i organizacji. Wybrane zagadnienia, red. Z. Ratajczak A. Bańka, E. Turska, Wydawnictwo Uniwersytetu Śląskiego, Katowice, 2004, s. 59-117.

${ }^{6}$ Por. B. Worek, K. Stec, D. Szklarczyk, K. Keler, Bilans Kapitatu Ludzkiego. Raport podsumowujacy pierwsza edycję badań realizowana w 2010 roku, PARP, UJ, Warszawa-Kraków, 2011, www.bkl.parp.gov.pl (otwarty 20.10.2012). 
dla jak najszerszego grona odbiorców, w tym także dla osób dorosłych pracujących oraz promowania i rozpowszechniania metod pomocnych w samodzielnym planowaniu kariery zawodowej.

Odzwierciedleniem wskazanych trendów są zmiany w podejściu do edukacji, zalecane m.in. w Strategii Uczenia się Przez Całe Życie ${ }^{7}$. Wdrożenie takich narzędzi, jak Europejskie Ramy Kwalifikacji ${ }^{8}$ czy System Transferu Osiągnięć dla Kształcenia i Szkolenia Zawodowego ECVET $^{9}$, mają ułatwić mobilność edukacyjną i zawodową oraz poszerzyć możliwości zdobywania kwalifikacji zawodowych i walidacji efektów uczenia się przez całe życie. Jednocześnie edukacja ma za zadanie przygotowywać do płynnego wkraczania na rynek pracy oraz aktywnego i satysfakcjonującego uczestnictwa w nim. Te przesłanki muszą wpłynąć na podejście i praktykę doradztwa zawodowego, którego istotnym celem staje się odpowiednie przygotowanie jednostki do samodzielnego planowania kariery i zarządzania nią.

Omawiany w niniejszym sprawozdaniu projekt „Naviguide” wpisuje się w zarysowane tu wyzwania, stojące przed doradztwem zawodowym. Ma on bowiem na celu promowanie i rozpowszechnianie metod poradnictwa grupowego wśród jak najszerszego grona odbiorców. Opracowany przez zespół partnerów międzynarodowy zbiór metod i ćwiczeń może stanowić pomoc zarówno dla doradców, jak również dla osób indywidualnych, chcących samodzielnie planować i zarządzać własną karierą. Jednym z założeń realizatorów projektu jest przekonanie, że planowanie własnej kariery to proces ustawiczny, całożyciowy, zatem człowiek musi zostać wyposażony w odpowiednie umiejętności i narzędzia, wspomagające go w tym obszarze przez całe życie.

7 Por. Rezolucja Rady z 27 czerwca 2002 roku w sprawie uczenia się przez całe życie, Decyzja Parlamentu Europejskiego i Rady z dnia 15 listopada 2006 roku w sprawie programu i działań zakresie uczenia się przez całe życie.

8 Zalecenie Parlamentu Europejskiego i Rady z dnia 23 kwietnia 2008 roku w sprawie ustanowienia Europejskich Ram Kwalifikacji dla uczenia się przez całe życie (2008/ C111/01).

9 Zalecenie Parlamentu Europejskiego i Rady z dnia 18 czerwca 2009 roku w sprawie ustanowienia europejskiego systemu transferu osiągnięć w kształceniu i szkoleniu zawodowym. 
Projekt jest realizowany od października 2011 roku przez sześć państw partnerskich: Francję, Chorwację, Irlandię, Austrię, Polskę i Turcję. Koordynatorem projektu jest Karin Steine, która reprezentuje austriacką firmę Abif. Polskę reprezentuje Społeczna Akademia Nauk w Łodzi.

Głównym celem projektu jest utworzenie międzynarodowego zbioru metod $\mathrm{z}$ zakresu doradztwa zawodowego w ujęciu grupowym oraz budowanie europejskiego systemu doradztwa zawodowego. Jedną z przesłanek jest także upowszechnianie i rozbudowywanie istniejącej już austriackiej bazy metod i technik wspomagających pracę doradców zawodowych, należącej do austriackiego Publicznego Biura Pośrednictwa Pracy (AMS) ${ }^{10}$. W projekcie „Naviguide” katalog ten miał zostać przekształcony we wspólną bazę metod dla doradców zawodowych w Europie.

Na początku projektu partnerzy sporządzili syntetyczne raporty dotyczące sytuacji doradztwa zawodowego w swoich krajach ${ }^{11}$. Przygotowanie raportów miało na celu przybliżenie sytuacji doradztwa zawodowego w poszczególnych krajach, znalezienie różnic i podobieństw, a także określenie przyszłych wyzwań, stojących przed doradztwem zawodowym w poszczególnych krajach partnerskich.

Kolejnym krokiem była analiza metod i technik doradczych stosowanych w krajach partnerskich, spośród których partnerzy dokonali wyboru 102 metod opracowanych w Austrii i we Francji. Metody te oraz techniki i poszczególne ćwiczenia zostały przetłumaczone na języki krajów partnerstwa. Następnie utworzona została elektroniczna baza metod w językach krajów partnerskich (Austrii, Chorwacji, Francji, Irlandii, Polski i Turcji) ${ }^{12}$, a w przygotowaniu jest płyta $\mathrm{CD}$, mająca zawierać bazę metod oraz podręcznik dla doradców. Elektroniczna baza jest dostępna dla wszystkich zainteresowanych i można korzystać z niej bez konieczności logowania się. Możliwe jest zdefiniowanie kryteriów

10 Por. www.ams-forschungsnetzwerk.at (otwarty 20.10.2012).

11 Raport dostępny na: http://www.naviguide.net/reports/Naviguide-Synthesis-Report-PL.pdf (otwarty 20.10.2012).

12 Dostępny na: http://www.naviguide.net/methods/methods.asp?lang=48\&Spage=8 (otwarty 20.02.2013). 
wyszukiwania takich, jak: obszar tematyczny, grupa docelowa, rodzaj ćwiczenia, forma, czas trwania, tematyka oraz słowa kluczowe.

Zbiór metod podzielony został na 10 obszarów tematycznych:

- analiza potencjału,

- informacja zawodowa, zarządzanie informacją, orientacja na rynku pracy,

- rozwój kompetencji społecznych,

- oczekiwania, poznawanie się, formułowanie celów,

- orientacja, zmiana postaw, aktywizacja i motywacja,

- radzenie sobie z oporem, konfliktami, frustracją, rezygnacją, metody wzmacniania odpowiedzialności za grupę i poszczególnych uczestników,

- szkolenie praktyczne,

- wybór ścieżki kształcenia i zawodu,

- poszukiwanie, ubieganie się o pracę, znalezienie pracy,

- zakończenie kursu, opinie i informacje zwrotne.

Wyodrębnione obszary tematyczne dotykają wszystkich istotnych aspektów doradztwa. Praktyczne wskazówki, zawarte w ćwiczeniach, mogą służyć nie tylko doradcom, ale także samym zainteresowanym osobom poszukującym pracy. Duża grupa ćwiczeń skierowana jest na praktyczną pomoc (szkolenia praktyczne, znalezienie pracy) - np. zawierają porady, jak organizować wizyty stażowe w firmach, jak wykorzystywać te wizyty w procesie planowania kariery zawodowej. Wszystkie ćwiczenia są szczegółowo opisane w podręczniku dla doradcy ${ }^{13}$.

Ciekawym rozwiązaniem bazy jest wyszukiwarka, ułatwiająca znalezienie odpowiedniego ćwiczenia. W kryterium „rodzaj ćwiczenia” wyodrębniono następujące kategorie: burza mózgów - zadanie dla całej grupy, dyskusja na forum całej grupy, odgrywanie ról lub symulacja, praca dla całej grupy, praca indywidualna, praca w małych grupach, praca w parach, prezentacja, wywiady, zastanawianie się nad zagadnieniem - cała grupa.

13 Podręcznik dostępny na: http://www.naviguide.net/polish/handbook.asp?lan$\mathrm{g}=48 \&$ SPage $=7$ (otwarty 20.02.2013). 
W kryterium „grupa docelowa” można wyszukać ćwiczenia skierowane do następujących grup: bezrobotni dorośli, długotrwale bezrobotni, dorośli, kobiety po długiej nieobecności na rynku pracy, kobiety z zawodami technicznymi i w rzemiośle, osoby powracające na rynek pracy, osoby starsze, osoby z doświadczeniem zawodowym, młodzi stojący przed wyborem kariery zawodowej i ścieżki kształcenia, młodzi absolwenci, osoby dorosłe o pochodzeniu migracyjnym nie posiadające udokumentowanych kwalifikacji, osoby dorosłe o pochodzeniu migracyjnym nie posiadające wykształcenia, osoby dorosłe o pochodzeniu migracyjnym nie pracujące dotąd, osoby dorosłe o pochodzeniu migracyjnym posiadające udokumentowane kwalifikacje, osoby młode o pochodzeniu migracyjnym stojące przed wyborem kariery zawodowej i ścieżki kształcenia, osoby o pochodzeniu migracyjnym powracające na rynek pracy, osoby powracające do zdrowia, osoby zmieniające pracę i w trakcie reorientacji zawodowej, osoby, które niedawno weszły na rynek pracy.

Metody ujęte w bazie prezentowane są podczas warsztatów promujących projekt i metody, które organizowane są w krajach partnerskich ${ }^{14}$.

Jeszcze innym celem projektu „Naviguide” było budowanie wspólnej, europejskiej bazy kontaktów dla doradztwa zawodowego. W ramach prac projektu analizowano także sieci kontaktów w poszczególnych krajach, które umożliwiają doradcom dzielenie się wiedzą i doświadczeniami. Poniżej prezentuję wybrane fragmenty raportu, dotyczące informacji na temat sieci kontaktów, z których korzystają doradcy w poszczególnych krajach partnerskich, pomijając informacje na temat Polski, gdyż są one ogólnie dostępne ${ }^{15}$.

Irlandia, podobnie jak wszystkie pozostałe kraje partnerskie, jest członkiem sieci Eurodoradztwa. W Irlandii istnieją zarówno nieformalne, jak i formalne fora/sieci dla doradców zawodowych, umożliwiają-

${ }^{14}$ Harmonogram realizacji warsztatów dostępny na: http://www.dpf.swspiz.pl/index.php?url=news\&idn=268\&wj=1 (otwarty 20.02.2013)

15 Por. J. McCafferty, A. McCluskey, Raport syntetyczny dotyczacy doradztwa zawodowego $w$ ujęciu grupowym $w$ wybranych krajach europejskich, materiały projektu „Naviguide”, s. 18-19. 
ce im wymianę informacji i dzielenie się dobrymi praktykami. Formalne spotkania LESN odbywają się raz w miesiącu. Doradcy zawodowi mogą dzielić się wiedzą i omawiać różne problemy i kwestie związane z doradztwem. W 2011 roku powstało Krajowe Forum Doradztwa, które jest punktem komunikacji i współpracy osób związanych ze świadczeniem usług doradczych oraz miejscem rozwoju i wsparcia doradców zawodowych. Ponadto funkcjonuje Instytut Doradców Zawodowych instytucja reprezentująca ponad 1200 doradców zawodowych, organizująca konferencje i spotkania, w trakcie których jej członkowie moga nawiązywać kontakty i dzielić się doświadczeniami. Dwa razy w roku odbywają się nieformalne spotkania pracowników Urzędu Pracy z Ballymun i GEMS NI, w trakcie których doradcy zawodowi dzielą się doświadczeniami, omawiają metody doradcze. Spotkania te mają także charakter grup wsparcia.

Chorwacja od stycznia 2011 roku wchodzi w skład Europejskiej Sieci Całożyciowego Poradnictwa Zawodowego (ELGPN), której celem jest standaryzacja polityki dotyczącej całożyciowego doradztwa zawodowego w obszarze zatrudnienia i edukacji. Chorwacja jest również członkiem Międzynarodowego Stowarzyszenia Doradztwa Oświatowego i Zawodowego (IAEVG), które umożliwia wymianę doświadczeń między ekspertami na całym świecie poprzez publikacje i kongresy. Co roku przez CES organizowane są spotkania doradców zawodowych doskonalenia koordynacji pracy i współpracy doradców na poziomie krajowym. Ponadto wydział doradztwa zawodowego Chorwackiej Izby Psychologów oraz Chorwackie Stowarzyszenie Psychologiczne systematycznie organizują warsztaty, konferencje i spotkania, mające na celu wspieranie doradców w rozwiązywaniu problemów oraz dzielenie się doświadczeniami. W 2012 roku utworzono także Krajowe Forum Całożyciowego Doradztwa Zawodowego.

We Francji seminaria i konferencje dla doradców organizowane są systematycznie przez różne instytucje. Należą do nich między innymi: INETOP, CNAM i IISC (Institut International de Sociologie Clinique). Regionalne centra informacji o szkoleniach i uczeniu się przez całe życie organizują fora wymiany informacji na temat wydarzeń skierowanych 
do doradców. Istnieją również sieci niezależnych doradców i trenerów (Société Française de Coaching). Ponadto fundusze ubezpieczeniowe szkoleń (OPCA i OPACIF) finansują usługę Bilan de competences oraz wymagają od akredytowanych centrów Bilan de competences tworzenia grup praktyczno-analitycznych, które umożliwiają wymianę doświadczeń między doradcami. Grupy te mają charakter formalny, spotykają się regularnie, a tematykę spotkań ustalają sami uczestnicy. We Francji istnieją także inne sieci CIBC (Centres de bilans de competences) oraz krajowe sieci misji lokalnych (missions locales), które organizują różnego rodzaju wydarzenia, tworzą nieformalne sieci wymiany informacji dla doradców.

W Turcji krajowa organizacja ds. zatrudnienia ISKUR posiada również nieformalne forum dla swoich pracowników, gdzie mogą wymieniać się doświadczeniami. Jednak partnerzy z Turcji sygnalizowali potrzebę zwiększenia zarówno liczby doradców, jak również standaryzacji procesu szkolenia i usług oraz możliwości dzielenia się wiedzą. Brak bowiem w Turcji standaryzacji szkolenia doradców oraz usług doradczych.

W Austrii funkcjonują zarówno sieć, jak i liczne stowarzyszenia, które zajmują się kwestią zapewnienia jakości doradztwa. Są to: Profesjonalne Stowarzyszenie Austriackich Doradców Zawodowych (VBB Verband für Berufs- und Bildungsberatung), Stowarzyszenie Doradców Edukacyjnych i Zawodowych (ÖVBBL - Vereinigung für Bildungs-, Berufs- und LaufbahnberaterInnen). Wspierają nawiązywanie kontaktów i wymianę informacji między doradcami. Austria, tak jak Chorwacja i Polska, należy do Europejskiej Sieci Całożyciowego Poradnictwa Zawodowego (ELGPN). Jednym z istotnych działań Austrii w ramach sieci Eurodoradztwa jest nawiązywanie kontaktów między stronami zainteresowanymi doradztwem na poziomie krajowym i międzynarodowym.

Mimo że w Polsce doradztwo zawodowe jest jako subdyscyplina naukowa bardzo rozwinięte, wciąż brakuje w praktyce systemowych rozwiązań, które obejmowałyby wszystkie zainteresowane doradztwem grupy. Ponadto widoczne są słabe ogniwa, które obniżają efektywność 
doradztwa. Przykładem jest zapis w rozporządzeniu MEN, dotyczący doradztwa w szkole, który z jednej strony obliguje dyrektorów szkół do realizacji działań związanych z wyborem kierunku kształcenia i zawodu oraz planowaniem kształcenia i kariery zawodowej w celu wspomagania uczniów gimnazjum i szkoły ponadgimnazjalnej w podejmowaniu decyzji edukacyjnych i zawodowych, $\mathrm{z}$ drugiej zaś nie zapewnia możliwości zatrudnienia doradcy zawodowego w każdej szkole ${ }^{16}$. Praktyka pokazuje, że zapis ten nie zapewnia wszystkim uczniom uczestnictwa w systematycznym i kompleksowym programie w zakresie doradztwa edukacyjno-zawodowego, czego efektem jest zwiększenie prawdopodobieństwa podejmowania przez uczniów nietrafnych decyzji edukacyjnych bądź zawodowych. Następstwem tego zaniedbania jest narastanie bezrobocia strukturalnego oraz bezrobocia wśród młodych ludzi i absolwentów.

Przygotowanie do planowania kariery zawodowej nie dotyczy jednak tylko młodzieży. Obecnie, w dobie ciągłych zmian i fluktuacji pracowników osoby pracujące w każdym wieku coraz częściej borykają się z pytaniami:

- jak zaplanować dalszą ścieżkę kariery?

- jakie kompetencje będą mi potrzebne w przyszłości? Gdzie mogę je zdobyć?

- skąd czerpać niezbędne informacje?

- kto i gdzie może mi w tym pomóc?

Pracujący dorośli także poszukują poradnictwa z zakresie planowania kariery i zarządzania nią, jak również doradztwa w zakresie dalszej edukacji. Podnoszenie wieku emerytalnego, zmiany w obrębie zawodów i wymagań zawodowych oraz przeobrażanie się stanu i struktury zatrudniania na rynku pracy w Polsce powodują, że osoby pracujące nie czują się pewnie i bezpiecznie, dostrzegają bowiem potrzebę dokształcania i doskonalenia zawodowego. Niestety często takim osobom poszukującym brakuje wiedzy, umiejętności i kompetencji, niezbędnych

${ }^{16}$ Por. Rozporządzenie MEN w sprawie zasad udzielania i organizacji pomocy psychologiczno-pedagogicznej (Dz.U. Nr 228, poz. 1487). 
w samodzielnym planowaniu własnej kariery. Brakuje kompleksowego systemu poradnictwa kariery dla dorosłych pracujących dostępnego dla każdego, bez względu na wiek czy poziom wykształcenia. Jak wspomniałam we wprowadzeniu, pracodawcy w Polsce niezbyt chętnie wdrażają procedury związane w planowaniem ścieżek karier dla pracowników, jak również oczekują od pracowników, że będą dokształcać się sami.

Opisany powyżej projekt „Naviguide” jest niewątpliwie jednym z ciekawszych pomysłów na promowanie poradnictwa zawodowego, dostępnego dla każdego odbiorcy oraz wzmacniającego sieci międzynarodowych kontaktów doradców i usług doradczych. Warto podkreślić raz jeszcze, że planowanie kariery zawodowej powinno być procesem całożyciowym, a każdy obywatel powinien mieć możliwość zdobycia wiedzy i umiejętności samodzielnego planowania kariery i efektywnego zarządzania nią. 